IRSH 55 (2010), Supplement, pp. 203-233 doi:10.1017/S0020859010000556 (C) 2010 Internationaal Instituut voor Sociale Geschiedenis

\title{
Hydro-businesses: National and Global Demands on the São Francisco River Basin Environment of Brazil*
}

\author{
Lucigleide Nery Nascimento \\ Department of Natural Resources and the Environment, \\ University of New Hampshire \\ E-mail: LNN_UNH@hotmail.com \\ Mimi LARSEN BECKER \\ Department of Natural Resources and the Environment, \\ University of New Hampshire \\ E-mail: mimi.becker@unh.edu
}

Summary: The São Francisco River provided very obvious, close-by forms of sustenance for local communities. Beginning in the mid-1950s, the river became the place for large hydro-electric facilities, large-scale flooding, and population resettlement. A decade later, the federal government began working on pilot irrigation projects that would lead to areas described today as the Brazilian California. Hydro-power for Brazilian cities such as Recife and Salvador and irrigation for grapes and mangoes destined for the United States and Europe are among the eco-system services this river supplies. The purpose of federal policies for the north-east went beyond mitigation of the consequences of droughts, the hydraulic approach, and started to follow an economic approach based upon development; as a consequence, river and user came to be distant from one another. The two major intensive uses of the river, electricity and irrigation, threaten the long-term sustainability of this system.

\footnotetext{
* The authors acknowledge the support from the American Association of University Women for an international doctoral fellowship and from the Graduate School of the University of New Hampshire for a dissertation year fellowship. The authors thank the Ruth Farrington Fund of the Department of Natural Resources and the Environment, the Natural Resources and Earth Systems Science Ph.D. Program, and the Graduate School of the University of New Hampshire for travel support to present the first version of this paper at the First World Congress of Environmental History, held in Copenhagen and Malmö, 4-8 August 2009. We are grateful for the referees' suggestions for improvements. Comments and questions should be addressed to Lucigleide Nascimento.
} 


\section{INTRODUCTION}

"[U]nder natural conditions nothing is ever just right: it is always too big or too little, too steep or too flat, too hot or too cold, too wet or too dry." The human use of the water resources of the São Francisco River (SFR) has long shaped the environment of the basin and of cities and towns along its course. The phrase quoted above was heard by an early sanitary engineer and environmentalist, the American Herman Baity, while working on improvements in water and sanitation access in the north-east of Brazil. ${ }^{I}$ The thought justified the transformation of nature pushed by the national elites from I950s onward. An alleged imperfect nature provided the means for progress and development of hydro-power and irrigated agriculture. But the Brazilian journey toward perfection has negatively impacted those who inhabited the edges of this waterway.

Starting in the r870s and lasting a century, the use of vegetation as steamboat fuel deforested and destroyed the riparian and inland forests of the Caatinga and Cerrado biomes. ${ }^{2}$ Extensive livestock ranching, rain-fed farming, and riparian agriculture naturally fertilized by the seasonal rise and fall of the river's water existed in the valley. The local economy included fishing and gathering. Erosion resulting from the natural processes of the basin and from land use deposited sediments in the river bed. Silting has been a major problem. In addition, other sources of pollution exist. The river has been the sink for industrial and domestic discharges, nutrients and pesticides run-off, and leaching through the soil profile.

Beginning in the mid-1950s, the river became the place for large hydroelectric facilities and flooding. The construction of infrastructure for river-flow control, hydro-power generation, and a steady water flow for

I. Quoted in Herman G. Baity, Relatório do Serviço Especial de Saúde Pública (SESP) sôbre o Vale do São Francisco (Rio de Janeiro, I95 I), p. I 59. According to Kastleman, Herman G. Baity received the first ever doctorate in sanitary engineering in the United States. He is also seen as a pioneer environmentalist because of his recognition of the importance of clean water and sanitation systems. He spent seventeen months in Brazil working on US-funded projects to improve health and sanitation; Linda Kastleman, "H.G. Baity: A Pioneering Environmentalist", Carolina Public Health, Fall (2007), p. 8.

2. Caatinga occupies about $734,478 \mathrm{sq}$. $\mathrm{km}$, I I per cent of the national territory, mostly in the Brazilian north-east. A long dry season, the irregularity and low volume of rainfall $(400-600 \mathrm{~mm})$, and the existence of intermittent and seasonal rivers characterize this biome. Cerrado extends over about 2 I per cent of the country's land area, predominantly in the nation's central zone. Temperatures range from $72^{\circ} \mathrm{F}$ to $81^{\circ} \mathrm{F}\left(22^{\circ} \mathrm{C}\right.$ to $\left.27^{\circ} \mathrm{C}\right)$ and the annual rainfall is on average $1,500 \mathrm{~mm}$. The Cerrado is rich in biodiversity. See Ministério do Meio Ambiente do Brasil, Áreas Prioritárias para Conservação, Uso Sustentável e Repartição de Benefícios da Biodiversidade Brasileira (Brasília, 2007); Carlos A. Klink and Ricardo B Machado, "Conservation of the Brazilian Cerrado", Conservation Biology, i9 (2005), pp. 707-713. On the history of navigation, see Zanoni Neves, "Rio São Francisco: Os Primeiros Navegantes e o Sistema Econômico Regional”, Ciência Hoje, 32:192 (2003), pp. 30-35, and idem, Na Carreira do Rio São Francisco: Trabalho e Sociabilidade dos Vapozeiros (Belo Horizonte, 2006). 
irrigation, transformed the river and basin. The once freely flowing waterway was turned into a sequence of managed lakes. These environmental changes impaired fish migration, impacting aquatic species and fishing. ${ }^{3}$ The flow alterations associated with the effects of mining and agriculture affected other uses, such as leisure-aesthetic enjoyment. For example, in Pirapora the distorted river's water and sediment turned small natural waterfalls used for social recreation into rocks covered by vegetation. In 2007, the Pirapora government dredged the river to remove silt and plants. ${ }^{4}$

The creation and operation of dams required resettlement, as in the case of the Sobradinho, of more than 60,000 people and the relocation of towns including Remanso and Casa Nova. In-migration also impacted municipalities. Population and city growth rose in the "poles" of development and urban zones. ${ }^{6}$ Secondary-level cities located at these clusters now host individuals and families from nearby zones who leave their homes as they are attracted by the prospect of jobs in corporate agriculture. In the past, their destinations had been mega-cities such as São Paulo.

Cities such as Juazeiro, Petrolina, and the surrounding towns of the lowermiddle São Francisco River Basin (SFRB) have felt the consequences of the reshaped and reshaping environment. Between 1972 and 1978 the construction of the Sobradinho hydro-power complex interrupted navigation 40 kilometers downstream. ${ }^{7}$ The works impacted the once busy port of Juazeiro, which had already lost some importance due to road transport and navigation problems caused by silting and low water. After its construction, the dam continued to spur the decline in navigation because the new environment of a wide, deep, windy, and wavy reservoir impaired the use of existing boats. ${ }^{8}$ The old vessels were not suitable for the reservoir. They capsized.

3. Yoshimi Sato and Hugo P. Godinho, "Migratory Fishes of the São Francisco River", in Joachim Carolsfeld et al. (eds), Migratory Fishes of South America: Biology, Fisheries and Conservation Status (Ottawa [etc.], 2004), pp. 195-232.

4. Luiz Ribeiro, "Começa Obra de Desassoreamento do Rio São Francisco em Pirapora", Jornal do Meio Ambiente (Niterói, 2007), available at http://www.portaldomeioambiente. org.br, last accessed on 19 April 2010.

5. Jane L. Collins and Greta R. Krippner, "Permanent Labor Contracts in Agriculture: Flexibility and Subordination in a New Export Crop", Comparative Studies in Society and History, 4I (1999), pp. 510-534.

6. Instituto Brasileiro de Geografia e Estatística, Censo Demográfico 2000: Migração e Deslocamento - Resultados da Amostra (Rio de Janeiro, 2000); Comitê da Bacia Hidrográfica do Rio São Francisco, Plano de Recursos Hídricos da Bacia Hidrográfica do Rio São Francisco (Salvador, 2004).

7. Agência Nacional de Águas et al., Projeto de Gerenciamento Integrado das Atividades Desenvolvidas em Terra na Bacia do São Francisco ANA/GEF/PNUMA/OEA - Subprojeto 4.5 (São Paulo, 2003), p. I05.

8. Superintendência de Desenvolvimento do Nordeste - SUDENE, Plano de Aproveitamento Integrado dos Recursos Hidricos do Nordeste do Brasil - Fase I - Estudo de Demandas Navegação Interior - Anexo V (Recife, I980). 
Inhabitants of the watershed traditionally practiced small-scale irrigation. But in 1968 the federal government began working on pilot irrigation projects that would lead to large areas being described as the Brazilian California. ${ }^{9}$ Irrigated agriculture replaced the local vegetation with orchards. Starting in the I970s, various regions of Brazil consumed tomatoes from the valley and manufactured tomato sauce produced from local irrigated agriculture by the food-processing industry. In the late I980s, fruit from the basin reached international consumers. The United States and Europe began importing grapes and mangoes. The western part of Bahia state in the SFR watershed is the largest producer of soya beans in the north-east, sending that commodity overseas. ${ }^{10}$

In this post-1950 era, hydro-businesses, meaning the use of water for entrepreneurial purposes - hydro-power and irrigated agriculture shaped and reshape communities and the natural setting of the SFRB. Hydro-businesses benefit from direct and indirect governmental support, in the form, for instance, of subsidies, dams, and roads. They also build upon unpaid environmental services, such as hydro-resources. In this area of Brazil, water is a limiting factor and its scarcity already poses conflicts among its users (e.g. irrigation vs hydro-power, fishing vs hydro-power). The environmental consequences are felt locally. But their origins are located in regional, national, and international contexts.

This article addresses two questions: how have local communities been transformed in order to meet national and international demands? And how have the two major uses of the river (electricity and irrigation) coexisted and influenced other activities? ${ }^{\text {II }}$ The environmental history of

9. According to Nanne, "the waters of the São Francisco River are producing a new promised land in northeastern Brazil. Instead of milk and honey, one finds the sweetest and juiciest fruits ever grown in the country. The key to this agricultural success is irrigation, which, in a little more than a decade, has transformed Brazil's hot, arid sertão region into a verdant orchard. The controlled water flow makes fruit mature more quickly and allows for larger and more frequent harvests. In 1993, the region produced 80,000 tons of fruit, earning some $\$ 40$ million for its 30 exporters"; Kaíke Nanne, "Notes on the Sciences: 'California' in Brazil”, World Press Review, 4I:I (I 994), p. 44. In 2008, it produced more than a million tons; Agência Sebrae, "Vale do São Francisco dobra Exportação de Frutas", in Abanorte (Janaúba, 2009), available at http:// www.abanorte.com.br/noticias/vale-do-sao-francisco-dobra-exportacao-de-frutas, last accessed on I9 April 2010.

ı. Ministério da Agricultura, Pecuária e Abastecimento - MAPA, “Agronegócio Brasileiro: Uma Oportunidade de Investimentos" (Brasília, 2004), available at http://www.agricultura. gov.br, last accessed on I9 April 2010; Tânia Bacelar de Araújo, "Northeast, Northeasts: What Northeast?”, Latin American Perspectives, 3 I:2 (2004), pp. I6-4I.

I I. Primary data were drawn from observations of the river and the surrounding environment, and from information gathered through seventy-six open-ended interviews with river users, managers, and researchers. Secondary data have been gathered by means of virtual and inperson visits to libraries located at, among other places, federal, state, and municipal agencies, non-governmental organizations, and universities. Data triangulation provided answers for the 
the SFRB reveals a stark shift in the use of the waterway. The pre-I950 period illustrates a close-knit relationship between users and the body of water, typical of a more basic survival approach. The river resources were used mainly by the local communities. In the post-I950 era, a more corporative perspective emerged and became the enforced alternative. The river yielded profits to those far away. The large urban centers of Brazil consumed hydro-power, and in the later I980s agricultural products from irrigated zones of the valley supplied national and international markets. The idea of an "agro-exporter nation" on the path of "national development" imposed environmental (e.g. reshaped environment), economic, and social changes upon locals. The new modus operandi focused upon hydropower to further industrialization, urbanization, and large-scale agriculture.

\section{THE CONTEXTUAL MAP}

Historically, Brazil has played the role of a primary product exporter, beginning in the sixteenth century with valuable hard woods. Over the centuries, many other agricultural products followed, including sugar, coffee, tobacco, rubber, and cocoa. The period between I 880 and I9I 3 marked the culmination of Brazil's long history as solely a supplier of tropical products. ${ }^{\mathrm{I} 2}$ At the beginning of the twentieth century, coffee and rubber were the most important Brazilian export items. But the collapse of the coffee export sector was one of the many consequences of the Great Depression. The world crisis worsened Brazil's financial condition. It also showed that the view of Brazil as an agro-exporter nation was not shared by all members of society. Producers (coffee and rubber interests, for instance) disagreed among themselves and some sectors wanted to modernize the nation. ${ }^{{ }^{3}}$

Indeed, the world economic crisis of the i930s provided a crucial moment for deepening Brazil's import-substituting industrialization which had begun in the late nineteenth century. But while the agrocommercial elites fought to limit industrialization, their opponents, technocrats in state bureaucracies, aspiring industrialists, and progressive commercial strata, struggled for its protection. The collapse of the world coffee market in the I930s can be pointed to as the defining moment of Brazil's industrial development.

Between the I930s and the early i990s the state provided, among other things, investment in basic inputs and infrastructure. The pro-growth

research questions. As a rule, Lucigleide Nascimento translated all the quotations from the interviews and the non-English literature.

I 2. Donald Coes, "Brazil", in Arthur Lewis (ed.), Tropical Development I880-1913 (Evanston, IL, I970), pp. I00-I 27 .

I3. Steven Topik, "The State's Contribution to the Development of Brazil's Internal Economy, 1850-1930", The Hispanic American Historical Review, 65 (1985), pp. 203-228. 
state developed the areas which the private sector did not want or could not undertake. ${ }^{14}$ Some sectors were thought to be the state's business. The 1934 Constitution (Articles Ir 8 and II9) and I934 Water Code (Articles 43, 63, and 139) established, for instance, that industrial use of waters, such as for hydro-power, should be undertaken or overseen by the state. ${ }^{\text {Is }}$

Between I945 and 1979 governmental economic policy was still based upon the r93os' idea of national development (Nacional-desenvolvimentismo). ${ }^{16}$ That time frame included two major periods. From postWorld War II to the beginning of the I960s, a permit system and high tariffs imposed restrictions on imported products. The nation used an import substitution model. The second phase, between I96 I and I979, was that of the export industrialization model, which ended up dominating until I989. During this period, Brazil expanded its sales abroad of manufactured items. ${ }^{17}$ The import substitution and export industrialization paradigms centered upon industrialization and urbanization, which required vast supplies of electric power.

But Brazil never stopped being an agro-exporter nation. From I960 to the mid-1980s, the state also instigated and regulated the modernization of agriculture. ${ }^{18}$ The federal government provided rural credit, fixed prices, and created research institutions such as the Brazilian Agricultural Research Corporation (EMBRAPA) in 1972. The support spurred the formation of agro-industrial complexes. Selected areas and programs received special concessions, such as ethanol production. ${ }^{19}$ The nation has also fought against the protectionism of the developed nations and their domestic and export subsidies and import restrictions. In the era of climate change, biofuels became the rising star in the country's export list, though they are now coming under increasing criticism. Thus, agribusiness has continued to be an important sector of the national economy.

I4. Jeff Frieden, "Third World Indebted Industrialization: International Finance and State Capitalism in Mexico, Brazil, Algeria, and South Korea", International Organization, 35 (I98I), pp. 407-43I.

I . Senado Federal do Brasil, Código de Águas (1934) e Legislação Correlata (Brasília, 2003); Presidência da República Federativa do Brasil, Legislação: Constituição da República Federativa do Brasil de 1934, available at http://www.presidencia.gov.br, last accessed on 19 April 2010. ı6. Heloisa Conceição Machado da Silva, "Deterioração dos Termos de Intercâmbio, Substitutição de Importações, Industrialização e Substituição de Exportações: A Política de Comércio Exterior Brasileira de 1945 a 1979”, Revista Brasileira de Política Internacional, 46 (2003), pp. 39-65.

I7. Ibid.; Frieden, “Third World Indebted Industrialization”.

I8. Arilson Favareto, "Agricultores, Trabalhadores: Os Trinta Anos do Novo Sindicalismo Rural no Brasil”, Revista Brasileira de Ciências Sociais, 2I (2006), pp. 27-44.

19. Ibid.; Jodenir Calixto Teixeira, "Modernização da Agricultura no Brasil: Impactos Econômicos, Sociais e Ambientais", Revista Eletrônica da Associação dos Geógrafos Brasileiros Seção Três Lagoas, 2:2 (2005), pp. $2 \mathrm{I}-42$. 


\section{THE NORTH-EAST AND THE SÃO FRANCISCO RIVER VALLEY}

European explorers discovered the mouth of the SFR in I 50I. Two main human currents conquered the valley from the north to the south of the basin and in the opposite direction, at the end of the sixteenth and seventeenth centuries respectively. Both waves established cattle ranches, which supported the expansion of the human population in the area. ${ }^{20}$ Indigenous native people, white Europeans, and escaped and African slaves inhabited the basin during Brazil's colonial times. ${ }^{2 \mathrm{I}}$

The 2,700-kilometer-long river rises in the mountains of Minas Gerais (Figure I overleaf). In its northern and then eastern journey to the Atlantic Ocean 168 tributaries join the São Francisco. The SFR system drains an area the size of Spain, Portugal, and Denmark, being 57 per cent located in a drought-prone semi-arid climatic zone. The scarcity of the precious resource made water into an element of concern in the valley, which contains about 8 per cent of Brazil's territory and residents. The Upper SFR in the south-east of the nation occupies I6 per cent of the area of the watershed and almost one-half of the total inhabitants of the basin, and includes the large metropolitan zone of Belo Horizonte. ${ }^{22}$

The significance of the SFR has included spiritual, cultural, ecological, and economic elements and meanings for the local, regional, and national populations. The cultural and social concepts relate fundamentally to the watercourse being a provider of environmental goods and services for subsistence: fish, water, and the fertility of riparian zones due to the replenishment of nutrients that the muddy water of the river leaves behind after floods. The affectionate name given to the river, "Velho Chico" (Old Francisco), captures the spiritual link. Faith and mythology have been important elements in the life of the SFRB's populations. ${ }^{23}$

Aquatic activities have included aesthetic enjoyment, swimming, watching steamship navigation, or simply gazing at the river. The SFR in Pirapora is Minas Gerais's beach. The state is landlocked. River transportation has been

20. Raymond E. Crist, "Cultural Crosscurrents in the Valley of the Rio São Francisco", Geographical Review, 34 (1944), pp. 587-61 2; Instituto Brasileiro de Geografia e Estatística IBGE, Enciclopédia dos Municipios Brasileiros - Grande Região Leste (O São Francisco) (Rio de Janeiro, I960); Geraldo Rocha, O Rio São Francisco: Fator Precipuo da Existência do Brasil, 3 rd edn (São Paulo, 1983).

2 I. Companhia de Desenvolvimento do Vale do São Francisco - CODEVASF, São Francisco o Rio da Unidade (Brasília, 1978).

22. Comitê da Bacia Hidrográfica do Rio São Francisco, Plano de Recursos Hídricos da Bacia. 23. Daniel R. Gross, "Ritual and Conformity: A Religious Pilgrimage to Northeastern Brazil", Ethnology, го (I97I), pp. I29-I48; Antônio Barbosa, "Situação Geopolítica", in idem, Bom Jesus da Lapa: Antes de Monsenhor Turibio, no Tempo do Monsenhor Turibio, Depois de Monsenhor Turibio (Rio de Janeiro, 1995), pp. 30-8I. 


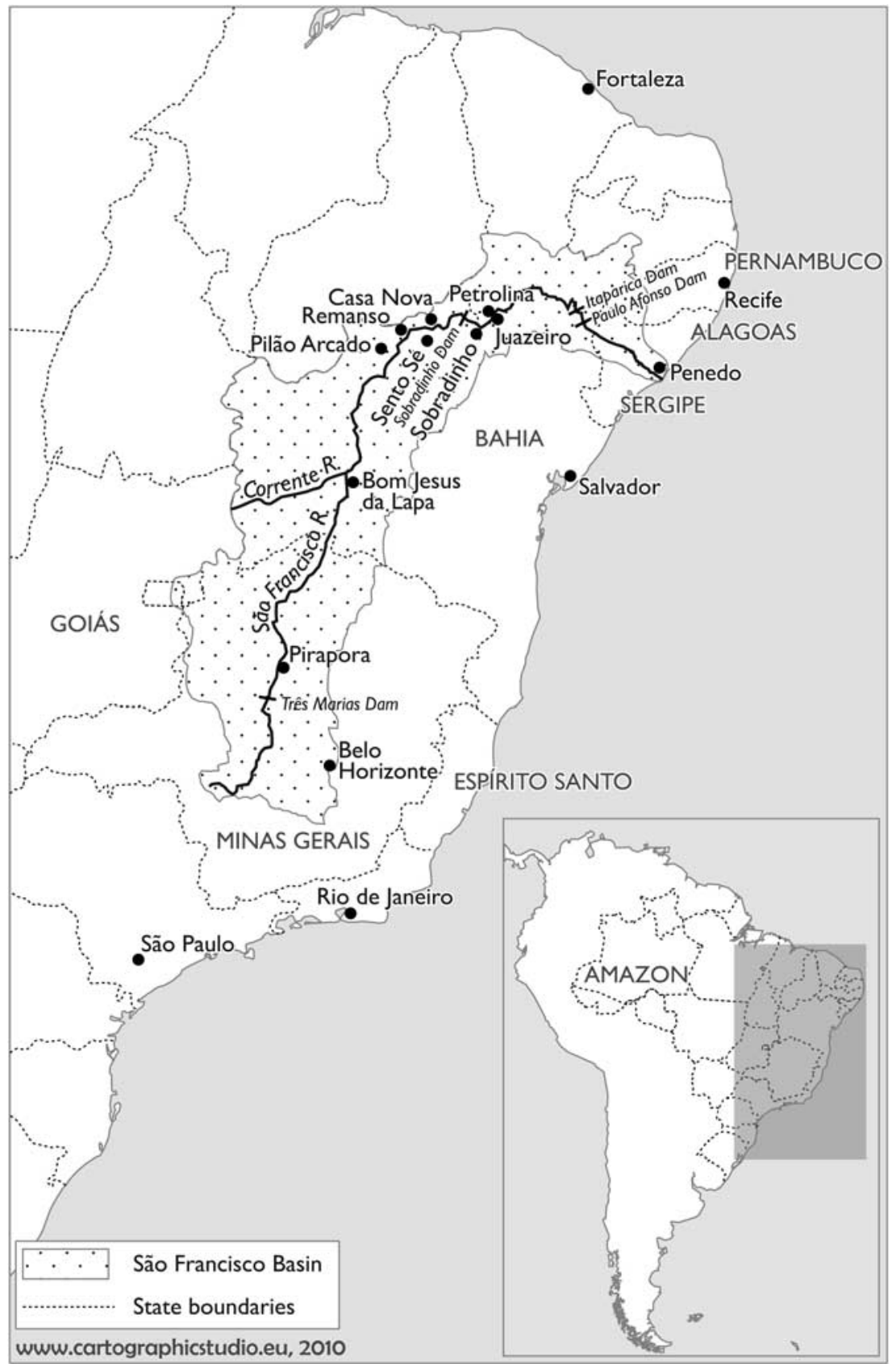

Figure I. The extension and location of the São Francisco River and Basin in relation to the Brazilian territory. 
an essential service, carrying everything: cargo, cattle, salt, fibers, mail, people, and money. ${ }^{24}$ A variety of vessels have traveled the SFR's waters - individual canoes (canoas), two or more canoes tied together by leather strips (ajoujos), sailboats, ferries, barges, tug-boats, and ships. Manpower as oarsmen or remeiros, wood stokers on steamers, and the entire crew or vapozeiros, in combination with diesel, wind, and river currents were the driving forces behind navigation. ${ }^{25}$ Mules in pack trains and then railroads linked the valley to the outside "developed" world. ${ }^{26}$ In the late I950s, Minas Gerais had the highest number of trucks in the valley. However, river navigation and animals were still the major form of transportation for the poor in the watershed area. ${ }^{27}$ The São Francisco Basin and the hinterland of the north-east known as Sertão provided raw material and received manufactured and food products. ${ }^{28}$ Processing and manufacture had always been a minor activity in the basin. ${ }^{29}$

Those living in the riparian zones, beiradeiros, or on the river bank's edges, barranqueiros, had a close link to the river. ${ }^{30}$ In interviews, one hears how they personify the river, as described by a Pirapora fisherman: "my parents fished and grew crops with Chico". ${ }^{\mathrm{I}}$ River people regarded the river as a paternal and spiritual being. As in real life, in one of his fictional literary works, Grande Sertão: Veredas, Guimarães Rosa noted a canoe man requesting the river's blessing. ${ }^{32}$ In his classic i950s three-volume

24. Luiz Flôres de Moraes Rego, O Valle do São Francisco: Ensaio de Monographia Geographica Separata da Revista do Musen Paulista da Universidade de S. Paulo - Tomo XX (São Paulo, 1936); Marcel Gautherot and Lélia Coelho Frota, Rio São Francisco, Recôncavo e Salvador (Rio de Janeiro, 1995).

25. Guilherme Fernando Halfeld, Atlas e Relatório Concernente a Exploração do Rio de S. Francisco desde a Cachoeira da Pirapóra até ao Oceano Atlântico, 2nd edn (São Paulo, 1994); Richard F. Burton, Explorations of the Highlands of the Brazil with a Full Account of the Gold and Diamond Mines (São Paulo, I977); Francisco Vicente Vianna, Memoir of the State of Babia (Salvador, I 893); “A Princesa do Sertão da Bahia: Um Documento da Importância de Juazeiro, a Bella Cidade sob a Coragem do São Francisco”, Babia Illustrada, April r9r 9; Murílo Carvalho and Ronaldo Kotscho, O Vale do São Francisco: Uma Viagem de Canoa, de Minas Gerais ao Oceano Atlântico (n.p., I989); Zanoni Neves, Navegantes da Integraçã: Os Remeiros do Rio São Francisco (Belo Horizonte, 1998), and idem, Na Carreira do Rio São Francisco.

26. The E.F. Bahia-S. Francisco railroad connected Juazeiro to Salvador in I894; see Bahia Illustrada, "A Princesa do Sertão da Bahia". According to President Nilo Peçanha's address to the Brazilian Congress, the Central do Brasil railroad met the São Francisco River in I9ro. See José Honório Rodrigues, “Aspirações e Interesses do Brasil”, Journal of Inter-American Studies, 3 (1961), pp. I47-185.

27. Instituto Brasileiro de Geografia e Estatística, Enciclopédia dos Municípios Brasileiros; Donald Pierson, O Homem no Vale do São Francisco, 3 vols (Rio de Janeiro, I972), II.

28. Aroldo de Azevedo, Brasil a Terra e o Homem: As Bases Físicas, 2nd edn (São Paulo, 1968). 29. Pierson, O Homem no Vale do São Francisco, III.

30. Burton, Explorations of the Highlands of the Brazil; Azevedo, Brasil a Terra e o Homem; Maureen Bisilliat, Terras do Rio de São Francisco (n.p., I986).

31. Fisherman and Fishermens' Association staff, interview, is May 2007, Pirapora, Minas Gerais. 32. João Guimarães Rosa, Grande Sertão: Veredas (São Paulo, 1983). 


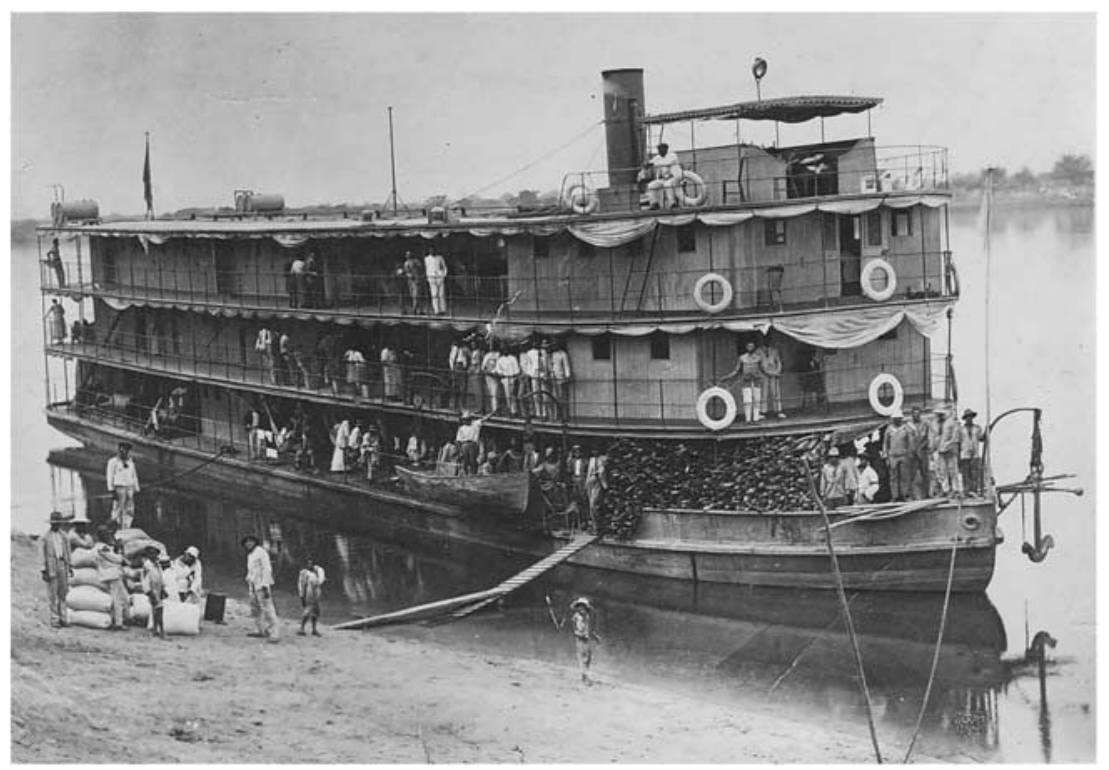

Figure 2. Steamboat navigation in the São Francisco River. Based upon other steamboat pictures, it is from the I930s. The steamships carried cargo, and first- and second-class passengers. Fuel occupied a large space. Steamers made frequent stops along the river to buy wood.

Source: Agência A Tarde de Noticias, Salvador, Babia, Brazil. Empresa Editora A Tarde S.A. Used with permission.

study of the river valley, O Homem no Vale do São Francisco, Pierson wrote about the transference of knowledge from adults to children. ${ }^{33}$ Indeed, the basin has been the context for the formation of the identity of several river-related groups, such as fishermen, small-scale riparian subsistence farmers, and boatmen (including remeiros and vapozeiros). They shared the beiradeiro/barranqueiro values and way of life, as shown by the two illustrations from Bahia's major daily newspaper (Figures 2 and 3). The SFRB was their universe. My interviewees said that the stream is the "soul" of those who inhabit its riparian zone. ${ }^{34}$ The waterway was their "left and right arms" 35 and "source of life" and livelihood. ${ }^{6}$ The "traditional ecological knowledge" that was transferred throughout generations influenced their beliefs. ${ }^{37}$

33. Pierson, O Homem no Vale do São Francisco, III.

34. Historian, interview, 17 May 2007, Pirapora, Minas Gerais.

35. Fisherman 2, interview, I 8 May 2007, Pirapora, Minas Gerais.

36. Small farmer in irrigated agriculture, interview, I 3 June 2007, Petrolina, Pernambuco.

37. Fikret Berkes, Johan Colding, and Carl Folke, "Rediscovery of Traditional Ecological

Knowledge as Adaptive Management”, Ecological Applications, Io (2000), pp. I 25 I-I 262, I 252. 


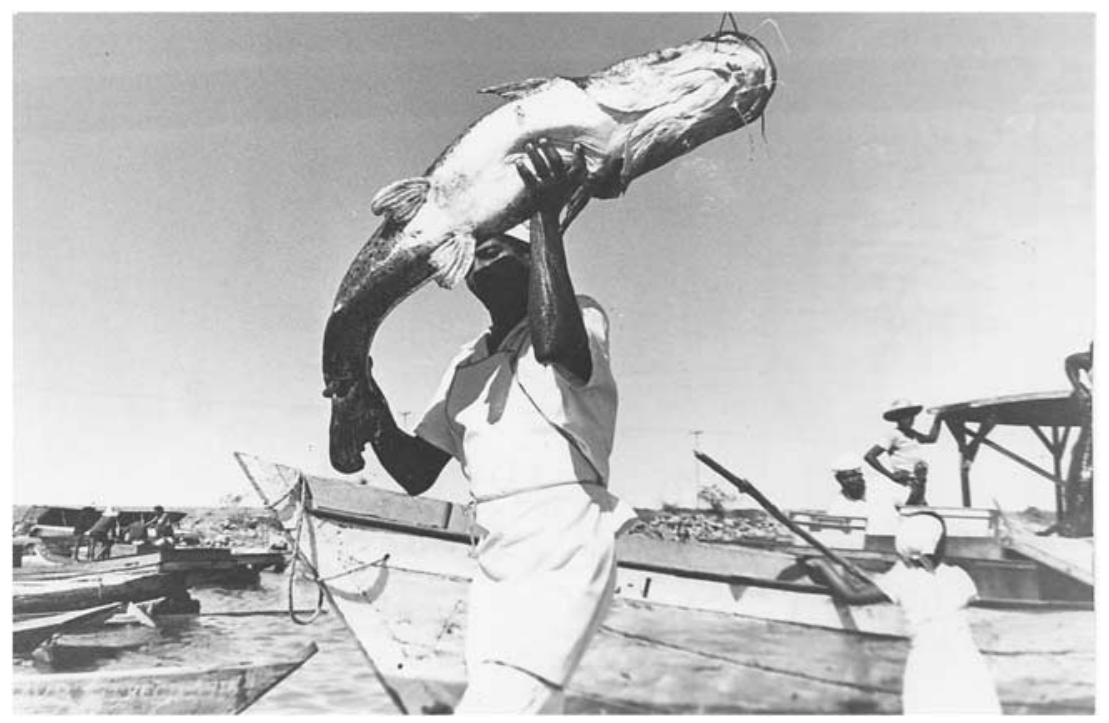

Figure 3. The Surubim fish, a prized native species of the São Francisco. The picture was republished on 30 March 1990. The reduction in population and size of this fish has been an indicator of the environmental degradation of local aquatic ecosystems.

Source: Agência A Tarde de Notícias, Salvador, Babia, Brazil. Empresa Editora A Tarde S.A. Used with permission.

Interviewees' memories portray the SFR as a multiple-use resource. They especially mentioned its long history as a source of transportation, fish, and water. The recollections of older generations of the past sixty years depict a healthier, deeper, and richer fish- and shrimp-stocked river than today. It helped them survive even during difficult times. Droughts and inundations occurred, but locals understood the river. They reported that "floods used to bring fish", ${ }^{3}$ and they also knew how, when, and where to fish, farm, and navigate Chico's waters. The interviewees have observed the environmental degradation of the river, and the trend of impaired uses throughout time (in relation for instance to navigation, fishing, and the lack of flooding of lagoons - which had allowed fish growth - and of rice fields).

Nevertheless, traditional life in riparian municipalities was full of challenges. Navigation was difficult especially during droughts and lowwater seasons. Boats got stranded on sandbanks and could not access docking sites. Lack of precipitation did not allow inland rain-fed fields and reduced the yields in riparian zones. The river's natural characteristics impaired navigation too. In some sections, namely Pirapora and Sobradinho, 
waterfalls and rapids formed the river's bed and channel. Besides, silting from deforestation and agriculture worsened the problem of the creation of sediment banks, c'roas. Deficient infrastructure made small-scale growers vulnerable; when not losing their crops totally, producers needed to sell the harvest for low prices due to the impossibility of access to alternative buyers. Floods used to fertilize and irrigate the land for riparian agriculture, but extreme events also destroyed fields, towns, and urban infrastructure along the waterway. ${ }^{39}$ Federal agencies built walls to protect the locals from the river.

As in the nineteenth century, El Niños brought droughts, thus influencing the ecology and economy in the north-east of Brazil, as in various other parts of the world. ${ }^{4}{ }^{\circ}$ During the I877-I 879 and I95I droughts, alternatives implemented for the north-east followed the technical hydraulic approach: engineering solutions to provide access to water. The federal government funded the construction of water reservoirs in different parts of the region. Nevertheless, not many people had access to the precious resource even though the SFR was one of the few steady sources of water. The semi-arid zone covered a vast area of low demographic density. Drought relief programs did not reach everyone. Besides, the resource was often diverted into the hands of few, and distributed to people on the basis of political criteria. ${ }^{4 \mathrm{I}}$ Construction of infrastructure for public water supply on private lands exemplified these irregularities.

The I940s' and early 1950s' images and studies of the São Francisco Basin's towns and cities demonstrate the precarious access of the population to fresh water. In all too many instances, the water supply came from shallow wells, small precipitation retention reservoirs, and intermittent creeks and streams, and was produced by the labor of "aguadeiros" or "botadeiras de água", people who collected small volumes of water from the SFR and other bodies of water and sold them to households. This activity was both a necessary part of women's obligations and a paid occupation for others. Some cities had water delivered only to public fountains, chafarizes. Water carriers also obtained the resource from that infrastructure. They carried water in clay containers, large cans, and inside of a pumpkin-like fruit, on their head or in their hands. Mules and cattle carts carried barrels of water. ${ }^{42}$

39. Instituto Brasileiro de Geografia e Estatística, Enciclopédia dos Municipios Brasileiros. 40. Mike Davis, Late Victorian Holocausts: El Niño Famines and the Making of the Third World (London, 200I).

4I. Mary Lorena Kenny, "Drought, Clientalism, Fatalism and Fear in Northeast Brazil", Ethics, Place and Environment, 5 (2002), pp. I23-I 34.

42. Gautherot and Frota, Rio São Francisco, Recôncavo e Salvador; Baity, Relatório do Serviço Especial de Saúde Pública; Pierson, O Homem no Vale do São Francisco, I. 
Already, in the I950s, changes in water provision arrived with the establishment of new autonomous organizations. ${ }^{43}$ Influenced by a Brazil-United States (Rockefeller Foundation) accord, and with the support of the development agency for the valley, the Comissão do Vale do São Francisco (CVSF), the federal health agency, the Serviço de Saúde Pública (SESP), implemented partnerships with the governments of several municipalities to build or improve water treatment stations, leading to the creation of independent public water providers' systems, the Serviço Autônomo de Água e Esgoto (SAAE). Pirapora, Bom Jesus da Lapa, Juazeiro, and Penedo benefited from that intervention. ${ }^{44}$ The Chico's water and SAAE systems still provide the resource for those riverside towns. Other arrangements existed in several places. For example, the CVSF funded the drilling of wells to supply water to rural populations. ${ }^{45}$

The river granted obvious, close-by forms of physical and spiritual sustenance. A local interaction of river environment and human beings existed. "The population had the natural knowledge of the time $[\ldots]$ the fishing time, the harvest time $[\ldots] "{ }^{46}$ The long-term droughts, which afflict the basin every nine to twelve years, influenced the human-river environment link. The vast literature on drought and the north-east of Brazil argues that the scarcity of water drew many to riparian zones, closer to the river. ${ }^{47}$

After the I950s, federal policies for the north-east went beyond mitigation of the consequences of droughts and started to focus on other issues such as development, following a growth-based approach. A new understanding of the SFR was emerging. The geographical distance increased between the river and the users of its resources. In the I950s, people in Salvador and Recife started to receive electric power generated by the SFR. The building of Brazil's only oil production zone, outside the city of Salvador, also required electricity. ${ }^{8}$ The eco-system service influenced the lives of individuals living far away in growing urban zones. In population terms, Recife surged in the I950s and I960s. ${ }^{49}$

43. Elmo Rodrigues da Silva, "O Curso da Água na História" (unpublished Ph.D. dissertation, Escola Nacional de Saúde Pública, I998).

44. Salomão Serebrenick, O Desenvolvimento Econômico do São Francisco: Um Planejamento Regional em Marcha (Rio de Janeiro, 196I); Pierson, O Homem no Vale do São Francisco, I.

45. Serebrenick, O Desenvolvimento Econômico do São Francisco.

46. Religious figure I, phone interview, I 3 January 2007 , Barra, Bahia.

47. The literature on drought and the north-east includes: Teodoro Sampaio, O Rio São Francisco e a Chapada Diamantina (São Paulo, 2002); Euclides da Cunha, Os Sertões: Campanha de Canudos (São Paulo, 2005); and Aziz Nacib Ab’ Sáber, “Sertões e Sertanejos: Uma Geografia Humana Sofrida”, Estudos Avançados: Dossiê Nordeste Seco, I 3 (1999), pp. 7-59.

48. Marc W. Herold, "Between Sugar and Petroleum: Bahia and Salvador, 1920-1960", Revista Espaço Acadêmico, 42 (2004), available at http://www.espacoacademico.com.br/042/ 42 cherold_ing.htm, last accessed 6 August 2010.

49. Robert M. Levine, "Letter from Recife”, Luso-Brazilian Review, 7 (1970), pp. I I4-I 2 I. 


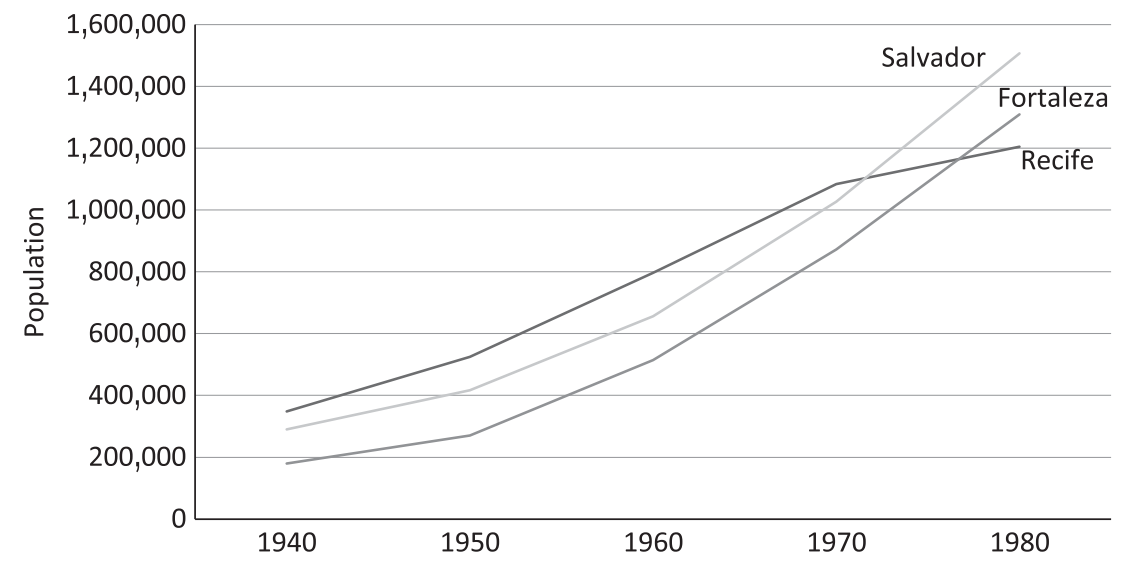

Figure 4. Urban population growth in three major cities of the coastal zone: Salvador, Recife, and Fortaleza (1940-1980).

Source: Derived from data from IBGE, 2003.

Federal censuses show that Salvador and Fortaleza even surpassed that city (Figure 4)..$^{50}$

Urban growth and industrialization created an unseen and unperceived, though strong, dependence and connection between human beings and the river environment which supplied the electrical power. In 200I, such strong dependence still existed when a drought caused a water shortage and led to urban blackouts and a mandatory electricity consumption reduction program. ${ }^{5 \mathrm{I}}$

In addition to the policies for the north-east, the federal government planned major programs for the valley based upon its economic development even before 1950. In the late i930s during the New State (Estado Novo), President Vargas saw the valley becoming "Brazil's economic spine". The watershed would include, besides river traffic, new roads and railways. Some saw the plan as a means to nationalize Brazil's wealth. ${ }^{52}$ Despite all the political rhetoric, no changes took place during the I930s. World War II caused a spike in the river's importance. The waterway became the only safe water transport link between the south and the north

5o. Instituto Brasileiro de Geografia e Estatística, Estatísticas do Século $X X$ (Rio de Janeiro, 2003), CD-Rom and online database at http://www.ibge.gov.br/seculoxx/default.shtm, last accessed on I9 April 2010.

51. Tribuna do Norte, "CHESF Ameaça Recorrer a Apagões", Tribuna do Norte, 4 October 200I; Agência Brasil - Radiobras, "Sinopse - Resumo dos Jornais", Sinopse Radiobras (Brasília, 200I), available at http://clipping.radiobras.gov.br, last accessed on i9 April 2010.

52. Frank M. Garcia, "Vargas Seeks Help of Private Wealth", New York Times, 27 February I $93^{8}$, pp. I and 27. 
of the country during the war, as German U-boats attacked Brazilian coastal ocean shipping. ${ }^{53}$

\section{HYDRO-BUSINESSES}

Eco-systems support a wide range of human uses. In turn, those applications influence natural processes again. In the Brazilian Amazon the national government redefined and changed how locals used natural resources to employ them for developmental purposes. ${ }^{54}$ If one compares the Amazon and the São Francisco Basin, in both cases the waterways used to be an integral part of the life of riparian communities. They used the river for fishing, natural irrigation, the fertilization of riparian lands, and for transportation. Interference from agents external to those systems produced destructive impacts - relocation of people and the elimination of areas of riparian agriculture resulting from the construction of dams and reservoirs. State development strategies redefined the Amazon, causing a move away from traditional historical roles of basic direct subsistence and into bauxite mining and hydro-power activities, turning small communities into boom towns. In the case of the SFR, the hydro-businesses of power generation and irrigation redefined and reshaped the natural system profoundly.

Hydro-power has played an important role in the provision of electricity for the nation. Before the I920s, manufacturing depended on accessible water power, but in the first two decades of the twentieth century few had observed the nation's natural potential, as described by the following sentence: "There is enough hydraulic force available in Brazil to turn the wheels of the world but the majority of these wonderful cascades are scarcely known by name." 55

By the I950s, electricity shortages and a growing demand for energy were a challenge for Brazilian development. ${ }^{56}$ Energy policy aimed at assisting the industrial development of the nation. In the north-east, governmental programs in the form of fiscal incentives, income tax exemptions, and public credit attracted industrial investment to major cities, such as Salvador and Recife. With the exception of the metropolitan area of Belo Horizonte and Pirapora in Minas Gerais state, Juazeiro in Bahia, and Petrolina in Pernambuco, industry was never the strong sector of the valley, though energy was.

53. Manoel Novaes, Memórias do São Francisco (Brasília, I989); Frank D. McCann, "Brazil and World War II: The Forgotten Ally. What Did You Do in the War, Zé Carioca?”, Estudios Interdisciplinarios de America Latina y el Caribe, 6 (1995), available at http://www.tau.ac.il/ eial/VI_2/mccann.htm, last accessed 6 August 2010.

54. Paul S. Ciccantell, "It's All about Power: The Political Economy and Ecology of Redefining the Brazilian Amazon", The Sociological Quarterly, 40 (1999), pp. 293-3 I 5.

55. Lilian Elwyn Elliott, Brazil Today and Tomorrow (New York, I917), p. 273.

56. Sam Pope Brewer, "Power Shortage Eased in Brazil", New York Times, 20 November I954. 


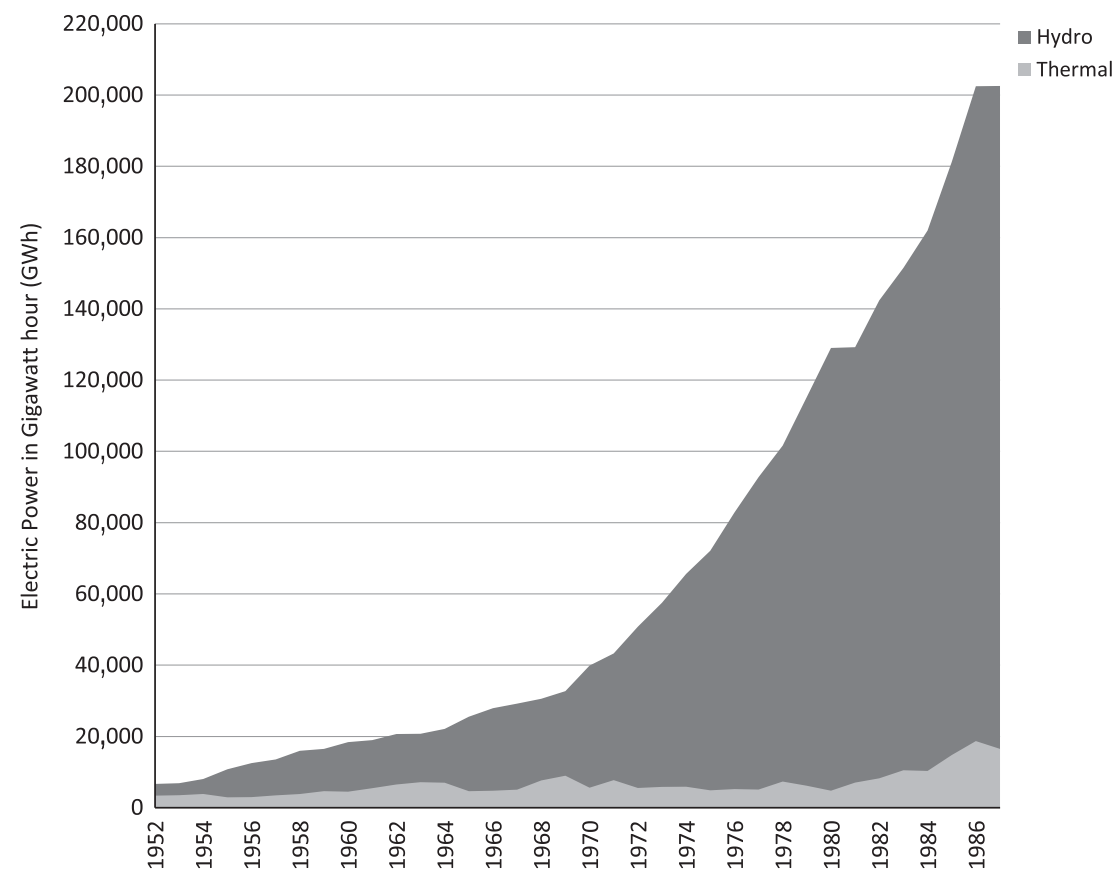

Figure 5. Electric power production in Brazil by source, 1952-1987, in gigawatt hours (GWh). Source: Derived from data from IBGE, 2003.

Paulo Afonso I, the first station producing electricity on a large scale in the SFRB, went online in 1954 . Through power lines, electricity started to flow outward from the valley in the same year. ${ }^{57}$ The station initially provided hydro-power to Pernambuco and Bahia. The north-east continued to expand its infrastructure, especially roads and electrical energy. ${ }^{58}$ In the I960s, hydro-power provided over 65 per cent of the nation's electricity, a share which steadily grew. Figure 5 displays both total Brazilian energy production and the proportion accounted for by hydro-power. ${ }^{59}$ In the I 970 s alone, four new stations started producing energy using the Velho Chico.

Nine dams control the river's flow. As with the other dams, Três Marias, the most upstream barrier holding back Chico's water, was intended to manage flooding, improve navigation, and make possible

57. Companhia Hidro Elétrica do São Francisco, so Anos Chesf: Companbia Hidro Elétrica do São Francisco - 1948-1998 (Recife, 1998).

58. Araújo, "Northeast, Northeasts: What Northeast?".

59. Instituto Brasileiro de Geografia e Estatística, Estatísticas do Século $X X$. 
large-scale irrigation and hydro-power generation. ${ }^{60}$ However, electricity became the principal output, followed later by water for irrigation. The damming of the SFR had quickly shifted from multiple to these dual purposes. Hydro-power infrastructure transformed the river and valley, managing the water's flow and assigning large areas of the valley as artificial lakes. The changes influenced irrigated agriculture, which helped support Brazil's role as an agro-exporter.

As already mentioned, Brazil's transnational economy has its roots in the nation's colonial past. ${ }^{61}$ The São Francisco Basin was connected with the global economy in a variety of ways before World War II. For example, at the end of the nineteenth century the region provided hides to the United States and Germany, and goat skins for ladies' gloves, book binders' leather, and high-grade shoes. ${ }^{62}$ Some thirty years later, a critical raw material of the valley, commercial quartz (silicon dioxide) crystal, was exported to Europe and the United States. Brazil was the only supplier of quartz, a component in the fabrication of radio station frequency controls, telephone equipment, lenses, and precision instruments. ${ }^{63}$ After the war, scientists at Westinghouse Electric learned how to grow quartz crystals, ending the need for Brazil's natural ones. Locals also collected the wild-growing caroá cactus (Neoglaziovia variegata) for fibers. During World War II, the United States imported the fiber for the production of cordage, paper, cloth, and bags. ${ }^{64}$

Brazil exported agricultural products partly to obtain foreign exchange. ${ }^{65}$ Between I96I and 2007, with the exception of 1979 and 1986 when Brazil fell behind Colombia, the nation was the world's leading coffee exporter. It was the number one exporter of raw sugar by volume from 1998 to $2007 .{ }^{66}$ By the 1980 s, a new group of Brazilian agribusiness billionaires had emerged which included some from São Paulo: José Cutrale and Carl Fischer, producing orange juice, and the soybean king,

6o. O Observador Econômico e Financeiro, CVSF Uma Comissão Recupera um Vale: de Três Marias a Sobradinho - Separata de O Observador Econômico e Financeiro (Rio de Janeiro, 1962).

6I. J.F. Riegelhaupt and S. Forman, "Bodo was Never Brazilian", The Journal of Economic History, 30 (1970), pp. 100-1 I6.

62. Marc W. Herold and Osvaldo Teixeira, "Empirical Foundations of Salvador da Bahia as Node of Commodity Networks, I850-1914", paper presented at the XVth World Economic History Congress, Utrecht, 3-7 August 2009.

63. Robert Burnett Hall, "American Raw-Material Deficiencies and Regional Dependence", Geographical Review, 30 (1940), pp. 177-1 86.

64. George Wythe, Brazil: An Expanding Economy (New York, I968).

65. Maria Auxiliadora de Carvalho and César Roberto Leite da Silva, "Vulnerabilidade do Comércio Agrícola Brasileiro", Revista de Economia e Sociologia Rural, 43 (2005), pp. 9-28. 66. Food and Agriculture Organization of the United Nations, "FAOSTAT Database: TradeExports-Countries by Commodities" (Rome, 2009), available online at http://faostat.fao.org/, last accessed on 20 April 2010. 
Olacyr Francisco de Moraes. ${ }^{67}$ During the 1970 s and 1980 , in the PetrolinaJuazeiro zone of the SFR Valley, the more resource-intensive and large-scale irrigated production of tomatoes, sugar cane, and fruit was launched. ${ }^{68}$ In the late I980s, almost half of the irrigated land of the basin was in this zone. ${ }^{69}$ Fruit juice and extracts from that agro-industrial area supplied the markets of a number of countries, including France and Switzerland. ${ }^{70}$ In 1987, grapes and mangoes from the valley began carving out a niche in the international market. ${ }^{7}$ The Netherlands, the United Kingdom, and the United States became important buyers. ${ }^{72}$ Soybeans completed the list of the valley's export products.

Several conditions favored agricultural production in the region. The low price of land and low cost of labor gave the north-east advantages in relation to other parts of Brazil and the rest of the world. ${ }^{73}$ In addition, the São Francisco Basin had a high annual temperature and bright sunlight. ${ }^{74}$ Lastly, the river's water was a free natural resource for producers in the valley. In practice, free water kept prices of agricultural products low. The main costs related to infrastructure, such as powering the pumps used in irrigation.

67. “As Estrelas do Campo", Revista Veja, 2 June I982, pp. I I 2-I 2 I, and "Pequena História de um Grupo que Gera US\$ 500 Milhoes em Divisas”, Revista Veja, I7 July 1982, pp. 40-4I.

68. José Maria Alves da Silva, Alberto Martins Rezende, and Carlos Arthur Barbosa da Silva, "Condicionantes do Desenvolvimento do Pólo Agroindustrial de Petrolina/Juazeiro", Revista Econômica do Nordeste, 3 I (2000), pp. 48-64.

69. Companhia de Desenvolvimento do Vale do São Francisco, Frutas Brasileiras: Exportação (Brasília, 1989).

70. Silva et al., "Condicionantes do Desenvolvimento".

7I. Jane L. Collins, “Gender, Contracts and Wage Work: Agricultural Restructuring in Brazil’s São Francisco Valley", Development and Change, 24 (1993), pp. 53-82, and idem, "Farm Size and Non Traditional Exports: Determinants of Participation in World Markets", World Development, 23 (1995), pp. I I03-I I I4.

72. Associação dos Produtores Exportadores de Hortigranjeiros e Derivados do Vale do São Francisco - Valexport, Valexport: Há 17 Anos Unindo Forças para o Desenvolvimento do Vale do São Francisco e da Fruticultura Brasileira (Petrolina, 2005), and idem, Valexport: Há I 8 Anos Unindo Forças para o Desenvolvimento do Vale do São Francisco e da Fruticultura Brasileira (Petrolina, 2006).

73. Carlos Estêvão Leite Cardoso and José da Silva Souza, "Fruticultura Tropical: Perspectivas e Tendências", Revista Economica do Nordeste, 3 I (2000), pp. 84-95. In the north-east of Brazil the price of an hour of work was US\$ 0.75 and in California US\$ 5-10 in the late I980s; Companhia de Desenvolvimento do Vale do São Francisco e do Parnaíba - CODEVASF, “Comparações" (Brasília, 2006), available at http://www.codevasf.gov.br, last accessed on 2I April 2010.

74. Andreas Voth, "The Transformation of the São Francisco Valley (Brazil) by Changing Development Policy and Export-Oriented Fruit Production”, paper presented at the Deutscher Tropentag, Berlin, I999; Cardoso and Souza, "Fruticultura Tropical"; Empresa Brasileira de Pesquisa Agropecuária - EMBRAPA, “A Região do Vale do Rio São Francisco” (Brasília, n.d.), available at http://www.cnpma.embrapa.br/projetos/prod_int/regiaosf.html, last accessed on 20 April 2010. 


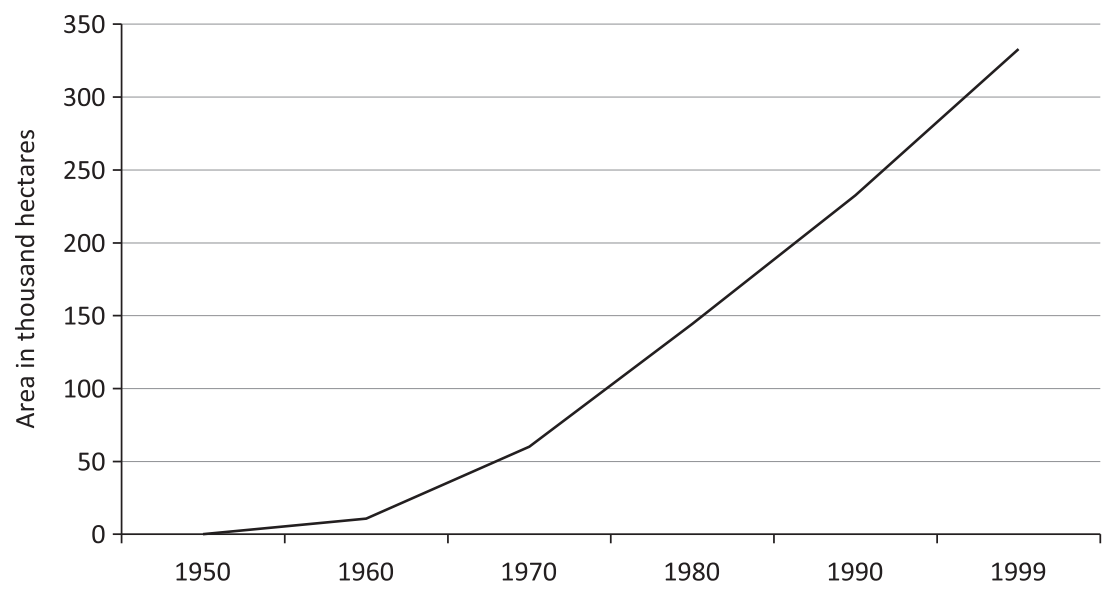

Figure 6. Irrigated land in the São Francisco River Basin. Source: Derived from data from CODEVASF, 2008.

By 1960, I0,800 hectares of the SFRB had been irrigated. By 1999, that figure had risen to 333,000 hectares (Figure 6), representing an average annual growth rate of 9.2 per cent for that 39 -year period. ${ }^{75}$

Irrigation allowed agricultural production beyond riparian and dryland agriculture (tradicional agricultura de sequeiro). ${ }^{76}$ Production became less dependent on the variability of the rainy periods. Irrigation permitted crop diversity, as well as spatial and temporal changes such as the location of the area of production and the time of the growing season in relation to the year. It transformed the landscape (Figures 7 and 8). Perennial and annual crops and water canals contrasted with the xerophytes and deciduous thorny scrub and trees of the semi-arid region.

Small-scale irrigated agriculture of onions and maize had operated in the riparian zones of the SFRB in the 1950s.77 During 1950 and 1952, the CVSF, a development agency for the watershed, had financed I,250 engines to pump water from the SFR to irrigate riparian land, especially in Bahia and Pernambuco and in the lower SFR. ${ }^{78}$ Hydro-power infrastructure, electricity,

75. Companhia de Desenvolvimento dos Vales do São Francisco e do Parnaíba, "Irrigação: Histórico e Vantagens" (Brasília, 2008), available at http://www.codevasf.gov.br/programas acoes/irrigacao/evolucao/, last accessed on 3 May 2010.

76. Emanoel de Souza Barros, Ecio de Farias Costa, and Yony Sampaio, "Análise de Eficiência das Empresas Agrícolas do Pólo Petrolina/Juazeiro Utilizando a Fronteira Paramétrica Translog", Revista de Economia e Sociologia Rural, 42 (2004), pp. 597-6I4.

77. Octavio Damiani, "Effects on Employment, Wages, and Labor Standards of Non-Traditional Export Crops in Northeast Brazil”, Latin American Research Review, 38 (2003), pp. 83-I I 2. 78. Superintendência do Vale do São Francisco - SUVALE, Relatório - Atividades: 1948-1968 (n.p., 1968); Novaes, Memórias do São Francisco. 


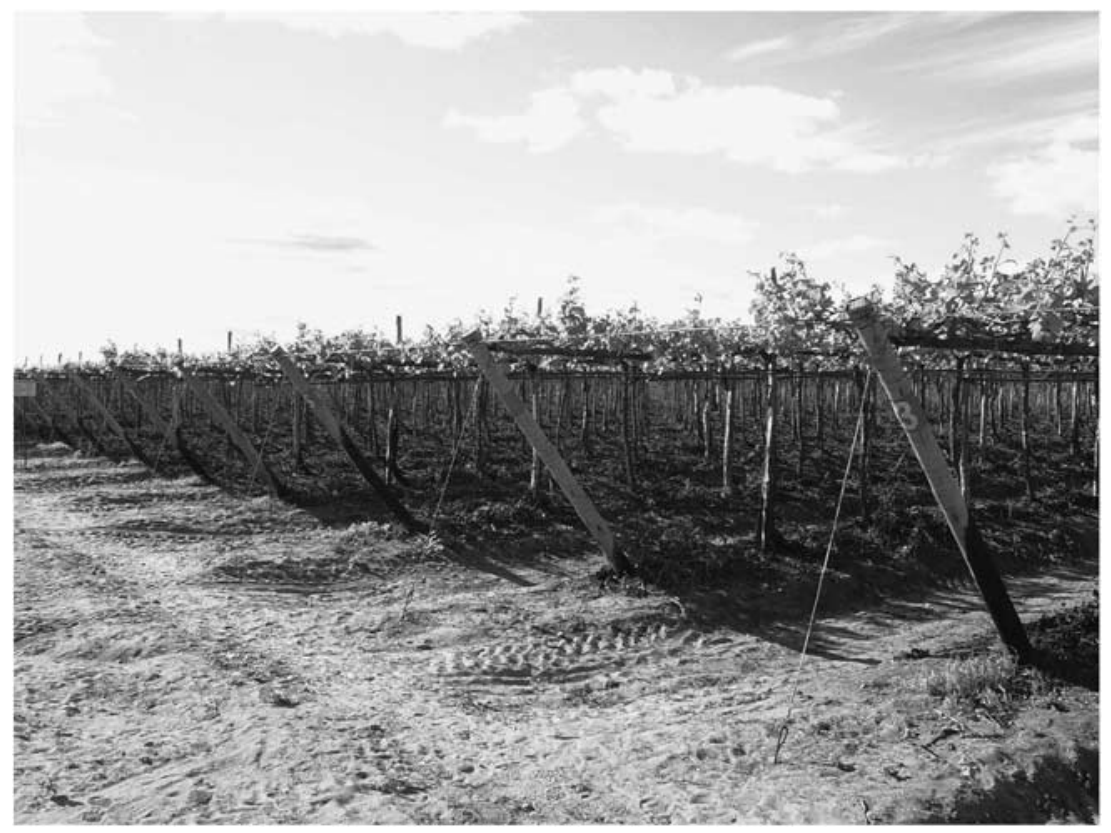

Figure 7. A vineyard at a private enterprise in Petrolina, Pernambuco, Brazil. Fruit culture is an important activity of the valley and grapes and mangoes are major products.

Photograph by Lucigleide Nascimento, 2007.

and the construction of canals, such as the one in Figure 8, and pumping stations made possible the existence of larger-scale irrigation systems. ${ }^{79}$

Since the I960s, the Companhia de Desenvolvimento dos Vales do São Francisco e do Parnaíba (CODEVASF), successor to the CVSF, and other federal agencies have been building the structural foundations for agroindustrial complexes in the valley. ${ }^{8 \circ}$ According to a former Bahia Federal Deputy, Manoel Novaes, the projects were well planned, and were intended to boost the production of food and create jobs to meet local needs. ${ }^{81}$ However, the projects had hidden costs, such as the overuse of water, run-off of fertilizers, salinization of soils, and ultimately a choice of products for export rather than local needs. The area in the north-east that used to grow traditional products (cotton and cassava for instance) has decreased since the 1970s. ${ }^{82}$ In the São Francisco Valley, the higher world market prices have led to an increase in the production and importance of

79. Collins, "Gender, Contracts and Wage Work".

80. Damiani, "Effects on Employment, Wages, and Labor Standards".

81. Novaes, Memórias do São Francisco.

82. Araújo, "Northeast, Northeasts: What Northeast?". 


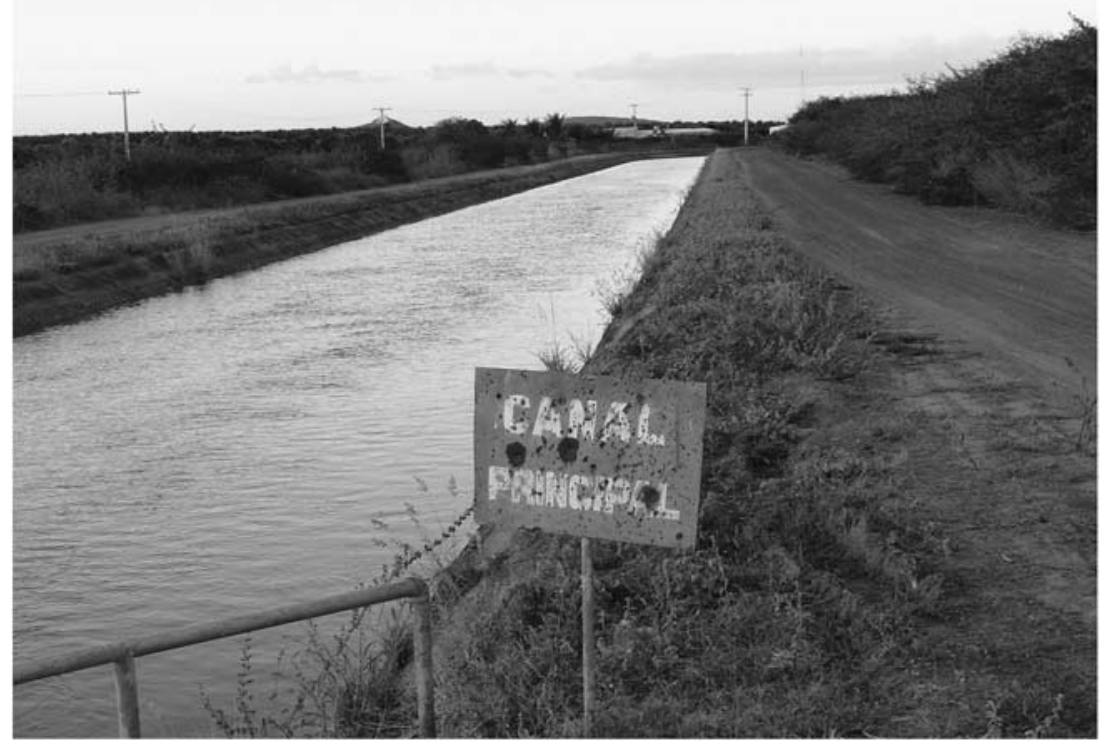

Figure 8. The main water canal which is an important infrastructure of an irrigation scheme. This publically built canal is located in the lower-middle-SFR in the municipality of Petrolina, Pernambuco, Brazil.

Photograph by Lucigleide Nascimento, 2007.

non-traditional crops, such as fruit (mangoes and grapes for example), raw produce for food processing (tomatoes for instance), and sugar cane. ${ }^{83}$

In the governmental irrigation zones, producers paid a water bill, but it covered only the use of infrastructure and not the water itself. In practice it acted as a subsidy to lower the price of agricultural products. As already mentioned, only the costs of infrastructure in governmental irrigated areas, such as the price for the electricity used to deliver the water, was charged. The 1997 Water Policy authorized payment for the use of water resources, but the system for the SFRB has not been fully implemented.

The area of land used for extensive cattle ranching declined. ${ }^{8}$ Irrigated agriculture reshaped and created vulnerability in the valley. ${ }^{85}$ The dependence on international markets made the valley susceptible to global crises and

83. Ibid.; Silva et al., "Condicionantes do Desenvolvimento"; Collins, "Farm Size and Non Traditional Exports".

84. Araújo, "Northeast, Northeasts: What Northeast?"; Silva et al., "Condicionantes do Desenvolvimento"; Collins, "Farm Size and Non Traditional Exports".

85. T.K. Marsden, "Reshaping Environments: Agriculture and Water Interactions and the Creation of Vulnerability", Transactions of the Institute of British Geographers, new series, 22 (1997), pp. 32I-337. 
fluctuations in the level of demand and price. It exposed the system to international market forces and product requirements. ${ }^{86}$ The new human uses of the valley's water have reconceptualized the good and the bad. The lack of rain was unfavorable for inland agriculture, demonstrating the vulnerability of locals to drought. ${ }^{87}$ It also reduced the yield in riparian zones because of the decrease in the size of the area subjected to inundation, leading to a poor agricultural season. But in the irrigated, controlled model of agriculture, rain became an uncontrollable variable that can damage agricultural production. ${ }^{88}$ Rains disrupted the planned nature of irrigated agriculture.

\section{MIGRATION AND FORCED MIGRATION}

At the end of the nineteenth century, north-easterners migrated to the Amazon during the rubber boom. ${ }^{89}$ In the i950s and i 960 s, people left to join the labor forces of São Paulo and Rio de Janeiro and to build Brasília. Indeed, following the trend of the broader region up until the I960s, population movement in the SFRB had been mostly outward. This outmigration was initially spurred by the recurrent devastating droughts, concentrated land ownership, and prevailing agricultural production models, then by the prospect of wage labor in urban construction and by the hope of higher living standards. Environmental refugees also sought water and shelter in the cities. Migration worsened social conditions in metropolitan zones, leading to the spread of shanty towns. ${ }^{\circ}$

In the r950s, the number of individuals born in the north-east but living outside of it grew at an annual rate of 8.8 per cent, more than twice the corresponding rate of 3.7 per cent in the I940s. The lower SFRB lost significant population in the 1950 s and $19605 .{ }^{91}$ On the other hand, the north-east did not attract significant migratory inflows from other regions, except from Minas Gerais and Espírito Santo. In 1970, 99 per cent of the population in the north-east had been born there..$^{2}$

The rural-urban migratory stream dominated in the areas of the middle and lower-middle SFRB during the $19605 .{ }^{93}$ In the north-east, rural to

86. Paulo de Queiroz Duarte, O Nordeste na II Guerra Mundial: Antecedentes e Ocupação (Rio de Janeiro, I97I).

87. Fernando Altenfelder Silva, Xique-Xique e Marrecas: Duas Comunidades do Médio São Francisco (Rio de Janeiro, 196I).

88. Marsden, "Reshaping Environments".

89. J.C. Oakenfull, Brazil in 1912 (London, 1913).

90. Araújo, "Northeast, Northeasts: What Northeast?".

91. Hélio Augusto de Moura, "O Balanço Migratório do Nordeste no Período 1950/1970", Revista Econômica do Nordeste, Io (1979), pp. 47-86.

92. Idem, “As Variações Migratórias no Nordeste: 1940/1970”, Revista Econômica do Nordeste, 3 (1972), pp. 20-47.

93. Idem, "O Balanço Migratório do Nordeste". 
urban migration continued during the I970s and I980s. Commerce and services attracted migrants to urban zones between 1980 and 1995, despite an economic crisis that hit the urban industrial sector harder than other areas. ${ }^{94}$

Migration is also associated with other causes. In some parts of the valley, the introduction of the new development approach of hydrobusiness destroyed the local social order of traditional ranching and agriculture, commerce, and fishing towns. The development-induced displacements disturbed the local way of life, forcing migration and adaptation to new ways of living, disconnected from the river. Hydropower management altered aquatic eco-systems and the zones which used to be naturally subjected to the seasonal rise and fall of the waters in riparian agriculture. Irrigation led to rising land values, often resulting in expropriation. The new model altered the existing work relations in the agricultural sector by reducing or eliminating older tenancy systems. Displaced smallholders moved to cities. ${ }^{95}$

Good examples of this tragic situation are provided by the Sobradinho and Itaparica dams, which required the resettlement of about 65,000 and 50,000 people respectively. ${ }^{96}$ The construction of the Sobradinho caused the relocation of four towns: Remanso, Casa Nova, Sento Sé, and Pilão Arcado. Few people ended up in the places in which they were supposed to be resettled. ${ }^{97}$ A new way of life was imposed as riparian inhabitants resettled into inland areas. "A lot of people who used to live from onion and garlic production $[\ldots]$ in [seasonally inundated] fertile soils in riparian areas [...] needed to change the production system [...]. They had to shift to another activity, such as goat herding." 98 Another interviewee said that, "once these people were sent to Caatinga $[\ldots]$ their numbers swelled the cities $[\ldots]$ ". ${ }^{99}$

In the case of the Itaparica dam, not all displaced residents received compensation. Given the informal traditional social system in which had they lived, they could not prove land ownership. The social and economic conditions of those the government resettled also often deteriorated. It took seven years for them to receive irrigation equipment to be able to farm the new lands. Violence and alcoholism increased in the community. ${ }^{100}$

94. Stephen G. Perz, "The Rural Exodus in the Context of Economic Crisis, Globalization and Reform in Brazil”, International Migration Review, 34 (2000), pp. 842-88I.

95. Collins and Krippner, "Permanent Labor Contracts in Agriculture".

96. Ibid.; Peter H. Gleick, "Water and Conflict: Fresh Water Resources and International Security", International Security, I8 (1993), pp. 79-I I2; Michael M. Cernea, "Public Policy Responses to Development-Induced Population Displacements", Economic and Political Weekly, 3 I (1996), pp. I5 I5-I 23.

97. Cernea, "Public Policy Responses".

98. Researcher, interview, 20 November 2006, Recife, Pernambuco.

99. Environmentalist and government staff, interview, I 3 June 2007, Petrolina, Pernambuco. I००. John Horgan, "The Itaparica Dam Project in North-Eastern Brazil: Models and Reality", Forced Migration Review, 4 (1999), pp. $25-28$. 
As Hilton observed, the implementation of governmental projects would save migrants a long walk to São Paulo. ${ }^{\text {IOI }}$ Irrigated agriculture attracts many to development "poles". Few find permanent work, forming a contingent workforce which finds jobs only seasonally. "Elsewhere in the region, on the periphery of the urban settlements of Petrolina and Juazeiro, settlements grew up to house the influx of migrants who formed the primary labor supply for most farms." ${ }^{\text {"O2 }}$ But the number of people who arrive every day is higher than towns and cities can support.

\section{ENVIRONMENTAL CHANGE AND ECOLOGICAL SUSTAINABILITY}

Ecological sustainability is critical to the long-term health and survival of both humans and non-humans. ${ }^{103}$ Ecological sustainability requires maintaining the integrity of natural systems. ${ }^{104}$ The protection of ecosystem health and integrity means respect for the system's carrying capacity and its resilience to stress. It also implies recognition of possible limits, and prevention of future damage. ${ }^{\text {IOS }}$ In the SFR case, this also means addressing water pollution and the destruction of aquatic populations, creating conditions for annual inundation to occur, as well as taking action to prevent new threats to the river's ecological sustainability.

Individual and cumulative effects on the river eco-system are many. River users, managers, and researchers from different localities have noticed the multiple changes during the last sixty years. Taking a holistic approach and comparing present with past conditions, the river has been categorized as a "sick" being or even a "dying river". Some predict that it will become a temporary river, as have many others in the semi-arid region which flow only during the rainy season. The threats to the sustainability of the SFR derive from, inter alia, the construction and operation of hydro-power infrastructure, urbanization and population growth (and their effects, such as the increase in raw sewage discharge), industry and mining, and agriculture and deforestation (cause and consequence). The focus here is upon electricity and irrigated agriculture, which are the forms of hydro-business in the valley.

Io I. Norman Hilton, United Nations Special Fund Project No. I8: Survey of the São Francisco River Basin Brazil - Interim Economic Report (n.p., I963).

I02. Collins and Krippner, "Permanent Labor Contracts in Agriculture", p. 520.

I03. Ecological sustainability in this case means the preservation of the physical, chemical, and biological characteristics of the life-support system and the system's capabilities as a provider of natural goods and services (ecosystem services).

I04. Mimi L. Becker, "Defining the Ecosystem Approach", in idem, Implementing a Binational Ecosystem Management Strategy in the Great Lakes Basin (Ann Arbor, MI, 1996).

I05. Robert Costanza, Bryan G. Norton, and Benjamin D. Haskell (eds), Ecosystem Health (Washington DC, 1992). 
Dams hold back water and sediments. An eighty-three-year-old retired boat worker, who also used to grow rice in Brejo Grande, beautifully described the changes in the river and what now takes place in the lower SFR:

When there were floods, the entire region was full of fish, because fish and shrimp used to come. The water flooded lagoons with that yellow water, vitamin rich, which resulted from the mud [the water] removed from the river's banks. [...] People grew rice [...]. It produced important rice. Today the water seems to be filtered, isn't it? The water is kept by the dam. When the dam lets the waters go $[\ldots]$ the water comes clean, without the vitamins. ${ }^{106}$

The staff of water treatment plants in the region of the lower SFR noticed changes too, including a reduction in the level of suspended sediments. ${ }^{107}$ The management of the river for hydro-power generation reduced the occurrence of natural floods which used to increase the level of the river seasonally and maintain riparian lagoons. Now dams prevent the flooding of such riparian water bodies. ${ }^{108}$ In the middle SFR, starting in Pirapora and in the lower SFR, the river is surrounded by lowlands that floods used to transform into lagoons. ${ }^{\circ 9}$ Fishing boomed in such an aquatic environment. ${ }^{110}$ The middle SFR including Bom Jesus da Lapa was an intensive fishing center. In 1968, fishermen caught 215 tons, in I 969 the figure was 385 tons, and in 1970 the catch amounted to 366 tons of fish. ${ }^{\text {II }}$ These numbers show the importance of the activity for the town and region.

The lack of periodic inundation inhibits fish from entering and exiting riparian lakes. ${ }^{\text {II }}$ It isolates those water bodies from the river's main channel for long periods and prevents migratory fish from returning to spawning sites. ${ }^{13}$ The dam itself also impairs fish migration. Many species

I06. Retired boat worker and rice farmer, interview, 4 June 2007, Brejão-Brejo Grande, Sergipe. 107. Water treatment plant staff I, group interview, I7 January 2007, Penedo, Alagoas.

108. M.C.C. Alvim and A.C. Peret, "Food Resources Sustaining the Fish Fauna in a Section of the Upper São Francisco River in Três Marias, MG, Brazil”, Brazilian Journal of Biology, 64 (2004), pp. 195-202.

109. Rego, O Valle do São Francisco.

i io. Pierson, O Homem no Vale do São Francisco, II.

I I. Serviço Federal de Habitação e Urbanismo - SERFHAU and Superintendência de Desenvolvimento do Nordeste - SUDENE, Relatório Preliminar de Desenvolvimento Integrado do Municipio de Bom Jesus da Lapa, Babia (n.p., 1972).

I I2. Jutta Gutberlet and Cristiana Simão Seixas, "Avaliação de Campo: A Situação SócioEconômica de Comunidades de Pesca no Alto, Médio e Baixo Rio São Francisco - Uma Avaliação Rápida e Independente" (Victoria, 2003), available at http://worldfish.org/PPA/ PDFs/Semi-annual\% 20I\% 20Portuguese/Ist\% 20s.a.\% 20port_C 3. pdf, last accessed on 4 May 2010.

I 1 3. Paulo dos Santos Pompeu and Hugo Pereira Godinho, "Effects of Extended Absence of Flooding on the Fish Assemblages of Three Floodplain Lagoons in the Middle São Francisco River, Brazil”, Neotropical Ichthyology, 4 (2006), pp. 427-433. 
of the SFR are migratory; they include surubim (Psendoplatystoma coruscans). ${ }^{\text {II }}$ Fish populations have decreased. Changes in species composition have also been observed. Surubim has become an endangered species, and tucunaré (Cichla spp.), an invasive species, now dominates the river's waters. Locals do not know how the tucunaré first arrived in the SFR. It is an aggressive fish that preys on other species. In Três Marias reservoir, small-sized fish declined significantly after the introduction of tucunaré. ${ }^{115}$

The changes in fish populations have compromised the livelihood of those who depend on the river's resources. All along the SFR, especially in the middle SFR, fishermen supported local and regional markets. They formed a homogeneous group sharing social and occupational identities. They behaved in similar ways and shared similar life objectives. The destruction of fishing means the annihilation of their former way of life. In bad agricultural seasons, the inhabitants of riparian cities will fish for food and also to sell if agriculture cannot support them and their families. ${ }^{116} \mathrm{~A}$ natural bias toward seeking subsistence from the river existed in the past, but environmental changes have increased this tendency.

The destruction of the traditional culture of fishermen does not imply that people do not fish for their sheer survival. Locals have noticed an increase in the number of fishermen. ${ }^{17}$ In 1985 , about 26,000 fishermen fished on the SFRB, ${ }^{\text {II }}{ }^{8}$ but many do not share the identity of the professional groups of the past. They fish for subsistence. "Today, it is difficult to sell [the fish]. There are more fishermen than buyers." In various regions of the SFR, fishermen are confident that many people fish now for lack of choice, while others are still proud of their traditional way of life. For them, the river is like a good boss. ${ }^{\mathrm{I} O}$ Unemployment, water pollution, the destruction of habitat due to the deforestation of riparian forests and the land filling of lagoons for urban and agriculture purposes, and overfishing have visibly impacted fish, fishing, and fishermen.

At the beginning of the twentieth century, an endless conflict between the river and the sea took place at the SFR's mouth. ${ }^{\text {I2I }}$ The volume of

I I4. Gutberlet and Seixas, "Avaliação de Campo".

I I s. Sato and Godinho, "Migratory Fishes of the São Francisco River".

i i6. Pierson, O Homem no Vale do São Francisco, II.

I I7. Fisherman and Fishermens' Association staff, interview, is May 2007, Pirapora, Minas Gerais.

I 18. GEO Brasil, O Estado do Meio Ambiente no Brasil: O Estado dos Recursos Pesqueiros Pesca Extrativa e Aqũicultura (Brasília, 2002).

I 19. Fisherman 3, interview, I8 January 2007, Penedo, Alagoas.

I 20. Fisherman I, interview, I7 January 2007, Penedo, Alagoas.

I2r. John Casper Branner, The Stone Reefs of Brazil, Their Geological and Geographical Relations, with a Chapter on the Coral Reefs [Bulletin of the Museum of Comparative Zoology at Harvard] (Cambridge, MA, 1904). 
water was high and swept the river's silt into the ocean. This fact did not eliminate the formation of islands and sandbanks near the SFR's mouth. ${ }^{\mathrm{I} 22}$ Today, the water is without the "vitamin", as a local from a municipality at the mouth of the SFR explained. It is "hungry water"; the sedimentstarved flow sculpts the landscape, eroding, transporting, and depositing sediment. ${ }^{123}$ At the river's mouth the load of sediment is reduced, and sea waves now accelerate beach erosion. ${ }^{\mathrm{I} 24}$ As a result, the small oceanside village of Cabeço has been completely washed out to sea.

Change in salinity affects species that grow in riparian zones. Saltwater destroys junco (Eleocharis elegans), a fiber-rich grass, and rice plantations. Two species of maçunim, shellfish, existed: one freshwater sort and the other saltwater. In the lower SFR, families spent time collecting maçunim

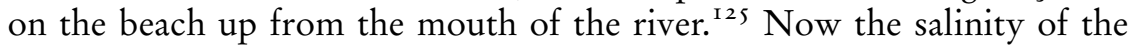
water is demonstrated by the catch of saltwater species in areas in which they were not common in the past.

Irrigated food production affects the natural system in both hydrological and ecological ways: subtracting nutrients, depleting and salinizing soils, polluting air, soil, and water due to the run-off of fertilizers and pesticides. ${ }^{\mathrm{I} 6}$ A 2002 analysis based upon qualitative information provided by environmental managers reported that about 38 per cent of the municipalities which comprise the SFRB suffered water pollution from three major causes: domestic sewage discharge, solid waste, and the use of agro-toxins and fertilizers. ${ }^{127}$ As with irrigation, fertilizer consumption in Brazil has been increasing since the late I960s. It jumped from 270,004 metric tons in I96I to $7,682,000$ in $2002 .{ }^{\mathrm{I} 28}$ Fertilizers are used in intensive agriculture, such as in fruit production in the north-east of Brazil. If improperly or over used, nutrients such as nitrogen can contaminate the water. Phosphorus causes eutrophication and depletion of oxygen in water bodies and the death of animal aquatic life and the impairment of human uses. Intensive irrigated

I22. Pierson, O Homem no Vale do São Francisco, I.

I 23. G. Mathias Kondolf, "Hungry Water: Effects of Dams and Gravel Mining on River Channels", Environmental Management, 21 (1997), pp. 533-551.

I 24. Ibid.; Abílio Carlos da Silva Pinto Bittencourt et al., "Wave Refraction, River Damming, and Episodes of Severe Shoreline Erosion: The São Francisco River Mouth, Northeastern Brazil”, Journal of Coastal Research, 23 (2007), pp. 930-938.

I 25. Fisherwoman and Fishermens' Association staff, interview, 7 June 2007, Brejo Grande, Sergipe; Pierson, O Homem no Vale do São Francisco, I and II.

I26. Sandra Postel, "Water and Agriculture", in Peter Gleick (ed.), Water in Crisis (New York, 1993), pp. 56-66; Food and Agriculture Organization of the United Nations - FAO, Fertilizer Use by Crop in Brazil (Rome, 2004).

I27. Instituto Brasileiro de Geografia e Estatística - IBGE, Pesquisa de Informações Básicas Municipais - Perfil dos Municípios Brasileiros: Meio Ambiente 2002 (Rio de Janeiro, 2005). I 28. Food and Agriculture Organization of the United Nations - FAO, "FAOSTAT Database: Fertilizers Consumption" (Rome, 2006), available at http://faostat.fao.org, last accessed on 22 April 2010. 


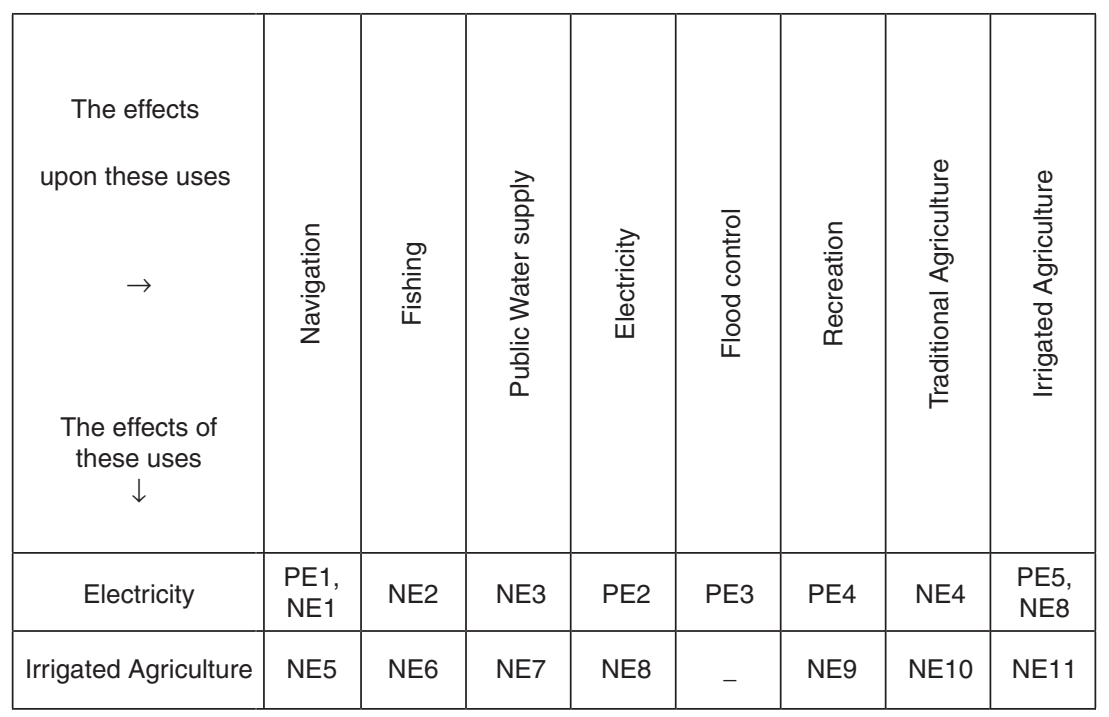

Figure 9. This matrix shows how the two major uses of the São Francisco (to generate electricity and to irrigate agricultural fields) can affect positively (PE), negatively (NE), or both, other uses of the eco-system services of the water body (e.g. navigation and fishing).

agriculture has resulted in the salinization of soils in the valley and waterways. In the Petrolina region, the water treatment plant uptake is downstream and close to a creek which crosses irrigated land. During winter, the salinity content is particularly high. ${ }^{29}$

Hydro-business in the SFRB has heightened the importance of analyzing trade-offs and opportunity costs. As in the case of the redefinition of the meaning of the Velho Chico for hydro-power and irrigation, the consequences are both impaired (negative effect - NE) and improved (positive effect - PE) uses of the SFR's waters (Figure 9).

NEI: In the Sobradinho Reservoir, the new environment to provide electricity impaired navigation of older-type boats because the lake was too windy. The river was not regulated for navigation.

NE2: Electricity impaired fishing. Hydro-power infrastructure transformed the flowing river into a sequence of managed lakes. It spoiled fish migration and their reproductive cycle. Producing electricity caused a decrease in the populations of fish, in the lower SFR for instance, because those populations cannot replace themselves in the altered habitat.

$\mathrm{NE}_{3}, \mathrm{NE}_{7}$ : The management of electricity and irrigation created concerns for public water supply, as in Penedo in the lower SFR, when air entered the water treatment plant system because the river's level was

I29. Water treatment plant staff 2, interview, I4 June 2007, Petrolina, Pernambuco. 
too low. ${ }^{130}$ In Petrolina, intensive agriculture is a source of contaminants in pre-treatment drinking water. ${ }^{\mathrm{I} 3 \mathrm{I}}$

$\mathrm{NE}_{4}$ : Electricity impaired traditional agriculture. The level of the river is no longer based upon natural conditions, but upon human management. Locals cannot apply their traditional knowledge to assess when the river will be high or low and when is the right time to farm and harvest.

NE5, NE6, NE7: Water withdrawn for irrigated agriculture might restrict and/or impair other uses, such as the maintenance of water to allow ecosystem life and for hydropower generation. In the basin, this use already impacts navigation and water supply for domestic uses. The Rio Salitre used to be a permanent tributary, the Rio Corrente had more flow in the past, and Minas Gerais's brooks and creeks are disappearing due to the intensive use of the water. Locals complained about the reduction in the flow of the tributaries and the contribution to the SFR. As one fisherman said, "as we need our arms, we need our legs, we need our head to govern our body; in the same way the big river needed its arms, the rivers that formed it". ${ }^{132}$

NE8: In future, managers will need to choose between one or the other use, water for irrigated agriculture or for electricity generation. For example, if the inter-basin water transference project (Transposição) of the National Integration Ministry takes place as proposed, the scheme will reduce CHESF's hydropower production by 2.4 per cent. ${ }^{133}$ The idea for this project has existed since the time of the Brazilian emperor D. Pedro II (I 840-I 889). The current inter-basin project has kindled both public support and opposition, including two hunger strikes and several court cases. This new large-scale infrastructure traversing part of the basin and other regions of the north-east involves northward and eastward running canals with a total of 720 kilometers of aqueducts, reservoirs, dams, and pumping stations, which will increase hydro-business. The project exemplifies what Richard Burton noted in the nineteenth century, namely that Brazil has had a bias toward monumental constructions since times past. ${ }^{\mathrm{I}}{ }^{34}$

Climate change is another consideration relating to water use and choices in the valley. Scientists agree that changing climatic conditions will affect hydrologic cycles. ${ }^{135}$ But the impact of those changes and our ability to cope with the problems they cause will not be distributed evenly

I30. Water treatment plant staff I, group interview, I7 January 2007, Penedo, Alagoas.

I3I. Water treatment plant staff 2, interview, I4 June 2007, Petrolina, Pernambuco.

I32. Fisherman I, interview, I7 January 2007, Penedo, Alagoas.

I33. Ministério da Integração Nacional do Brasil, Projeto de Integração do Rio São Francisco com Bacias Hidrográficas do Nordeste Setentrional - Relatório de Impacto Ambiental - RIMA (Brasília, 2004), p. I6.

I34. Burton, Explorations of the Highlands of the Brazil.

I35. A.P.M. Baede et al., "The Climate System: An Overview", in J.T. Houghton et al. (eds), Climate Change 200I: The Scientific Basis (Cambridge, 200I), available at http://www.grida.no/ climate/ipcc_tar/wgi/pdf/TAR-or.PDF, last accessed on 22 April 2010. 
around the world. ${ }^{136}$ They might trigger extreme events such as droughts and floods, increasing or decreasing river flows, evaporation, precipitation, and infiltration. The valley is already a water-deficit zone.

NE9: Irrigated agriculture might in the future create opportunities for beneficial effects, such as aesthetic enjoyment. The visit to wineries is still an incipient activity in the Petrolina and Juazeiro regions. The negative effects are more visible in the case of Pirapora, with tourist attractions in the waterfalls area - such as the beach at Minas Gerais - being impaired.

NEı०: Irrigated agricultural fields replaced areas of traditional crops and agriculture.

NE i : A limit exists to the extension of land and the size of production the SFR will be able to irrigate.

PEI: The construction of electricity-generating infrastructure, namely dams and reservoirs, improved river navigation when navigation was a highpriority use, as for example in Pirapora during the non-rainy season soon after the construction of the Três Marias dam. Then, energy became the most important river use, and the water body management focused on that.

PE2: A series of power stations and reservoirs along the river's course resulted in a better managed, fuller use of the river's flow for electricity generation.

$\mathrm{PE}_{3}$ : Electricity improved flood control. Extreme floods used to submerge towns and cities more often. Now, flooding occurs only if it does not impair hydropower management priorities.

$\mathrm{PE}_{4}$ : Electricity has created new means of recreation in the valley. For example, residents and tourists use the Paulo Afonso hydro-power infrastructure for aquatic sports and sunbathing on a sand beach, Prainha. The city is famous for its eco-tourism and new forms of sport. The bridge, which links Alagoas and Bahia and is supposed to save the population in the event of a dam-related disaster, is popular among bungee jumpers and rappellers.

PE5: Electricity improved irrigated agriculture. The construction of water reservoirs assured a steady supply of water and electricity to power the pumps.

\section{CONCLUSION}

The beginning of the I950s marked a new phase in the valley: dams altering production in riparian zones, water management for hydropower generation controlling the flooded area, and the federal government creating opportunities for irrigated agriculture in development zones. The redefinition of the uses of the SFR for hydro-power and

I36. Peter H. Gleick and Michael Kiparsky, "The Water and Climate Bibliography", in Peter H. Gleick et al., The World's Water: The Biennial Report on Freshwater Resources (Washington DC, 2004), pp. 228-233. 
irrigation imposed upon locals threatened their identity as barranqueiros and beiradeiros, making their living as riparian fishermen, boatmen, and subsistence farmers more difficult. The environmental changes impaired traditional uses, namely for fishing and riparian agriculture. The new values did not correspond to the realities of their society.

Hydro-businesses favored the production of crops for export, such as fruit and soybeans, which supports Brazil's international position as an important agro-exporter at the expense of meeting the demands of local people. Large-scale hydro-business does not address the needs of subsistence farmers and other local groups. The introduction of such a form of production tends to deepen the disparity between lower and higher economic classes. Few small farmers, tenants, and sharecroppers have benefited from the hydro-businesses of the late twentieth century. As one group of fishermen and fisherwomen put it:

A lot has changed, including the harvest we used to collect from the riparian zone where we used to grow crops after big floods. We produced a lot of cassava, watermelon, pumpkins, beans, and everything else. That came to an end $[\ldots]$. Such floods [natural ones] do not exist anymore [...] the richness of food ended too $[\ldots] .{ }^{137}$ 